\title{
[討議・回答]
}

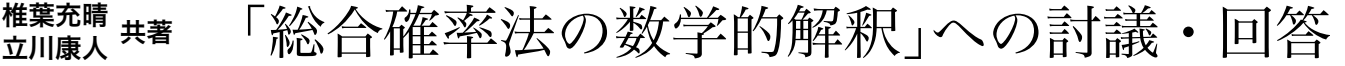

\author{
DISCUSSION/CLOSURE "MATHEMATICAL ASPECT OF SYNTHESIS PROBABILITY METHOD
} TO DETERMINE DESIGN FLOOD"}

(土木学会論文集 B1 (水工学)，Vol. 69, No. 2, pp. 101-104 2013 年 8 月掲載）

一討議者 (Discussion) 北野利一 (名古屋工業大学) - 高橋倫也 (神戸大学) - 田中茂信 (京都大学) Toshikazu KITANO, Rinya TAKAHASHI and Shigenobu TANAKA

\section{1. 総合確率法の経緯と残されている課題}

総合確率法は，河川の治水計画に確率を導入する当 時に提案されたようである。しかし，概念的で現実と 乘離する懸念があると考えられたため, 総合確率法そ のものの枠組みは, 淀川の治水計画には適用されなかっ た ${ }^{5)}$.ただし，総合確率法で検討されたアイディアの 幾つかは，1971 年に改訂された淀川の計画に部分的に 採用され，今日では，多くの河川整備計画に用いられ る手法となるに至っている。しかし，その際に取り入 れられたアイディアの 1 つであるカバー率が，近年の 河川整備基本方針の案をめぐって，議論の焦点の 1 つ になっている ${ }^{6)}$ 「「カバー率は 60〜90\%，引き伸ばし率 は 2 倍まで」という目安は，それぞれにあるものの，そ の扱いは恣意的とみなされることがある.

以上の上うな糿余曲折のある経緯のためか, 椎葉・ 立川7) が指摘するとおり, 総合確率法そのものの数学 的な導出を与える原著論文が無いようである。そこで, 利根川の河川整備基本方針 ${ }^{1)}$ で適用されている実績を 踏まえ, 我が国の多くの河川で慣用されてきた手法を 見直す可能性を探るためにも, 総合確率法の数学的な 根拠を論じることは意義深い.

総合確率法は, 式 (12) に示されるとおり，1つのピー ク流量 $Q_{p}$ に対して, 複数の降雨パターン $\xi_{i}$ を用い, それぞれの降雨量 $R_{i}$ に対する確率の算術平均により, 確率 $F_{\boldsymbol{Q}_{p \max }}\left(Q_{p \text { max }}\right)$ を求める. 椎葉・立川は, その根拠 が式 (9) にあることを明らかにしている。 これに対し, カバー率を用いる方法は，再現期間を与えて定まる 1 つの確率降雨量 $R$ に対し, 順次, 降雨パターンに応じ たピーク流量を求める。両者の違いについて, 図-3に ロや口印を描くことで明確にし，カバー率を用いる方 法に改善の余地が残っていることを彼らは言外にほの めかしている.

討議者らは, 大筋としては, 椎葉・立川の主張に賛成 する立場であるが，彼らの示す数学的解釈だけで終わ らせるのではなく，カバー率や引き伸ばし率の問題点 や，当時の淀川の治水計画に総合確率法が適用されな かった理由についても検討したいと考えている。そし
て，より積極的に総合確率法を活用するためには，彼 らの数学的解釈を土台に，まだ改良できる点があるこ とを示したい，そのためには，椎葉・立川の論文にお ける 4 つの仮定は，その妥当性をあえて議論しないと 断っているものの, その吟味も必要となる。これらの 点について, 著者らの意見を賜りたく, 討議を提出し た次第である。 なお，数式，図の番号抒よび参考文献 は, 読者の混乱や煩わしさを避けるため, 椎葉・立川 の論文からの連番とする。

\section{2. 超過確率に代わる生起率関数の導入}

\section{(1) 総合確率法が概念的とみなされる点}

降雨パターン $\xi_{i}$ は, 降雨の発生毎の降雨量 (図-1 の事 象発生毎の $R_{i}$ ) に基づくものである. 結果となるピー ク流量に対する確率を, 原因である降雨に遡って検討 する際に, 個々の降雨パターンに応じて検討している点 が, 総合確率法の本質であると考える。それゆえに, 降 雨量は, 年最大值の確率分布ではなく, 極大值 (事象発 生毎の值）の確率分布で議論されるべきである。した がって, 図-2における極大值の確率分布を用いて説明 されているとおり, 式(6)により, 降雨量 $R_{i=1 \sim N}$ となる 洪水事象が発生したときのピーク流量 $Q_{p}$ の確率分布 を求めることに, 総合確率法の原点があると理解する.

しかしながら, 椎葉・立川の 4.では, 降雨量および ピーク流量ともに年最大值分布に変換した議論をして いる. 特に, 図-3で示される概念図では, 降雨の発生毎 に決まる降雨パターン $\xi_{i}$ が描かれているにもかかわら ず，その縦および横軸は，年最大值 $Q_{p}$ max および $R_{\max }$ である。その結果, 式 (9) の洪水ピーク流量の年最大 值 $Q_{p \text { max }}$ の分布関数を誘導し, 実務に用いる計算式と して, 式(12)の近似式を得ている. 結果の確率は, そ の複数の原因の確率の算術平均で得られるものとして, 分かり易い解釈を与えている点に式(12)の特徵がある. しかし, 式 (9) および (12) は, 総合確率法の原点であ る極大值の確率ではなく, 年最大值に対する確率を用 いている.

大町 5) が指摘する「総合確率法が概念的で，具体的 
にイメージすることが困難」となる原因の 1 つは, 式 (12) で確率を合成する際に，得られるピーク流量に応 じたハイドログラフを 1 つのものとして提示できない (複数のグラフを 1 つに合成することは無意味となる) ことであるが，上述のとおり，年最大值分布による確 率を用いる点にもあると討議者らは考えている.

\section{(2) 実績降雨の抽出に用いる闒値を表示しない利点}

年最大值分布を用いて，式 (9) および式 (12) が導か れていることは，椎葉・立川により意図されたものと考 える，なぜなら，実績降雨を抽出するための閾值が明 示的に数式に現れる点が，極大值分布を用いた議論を 複雑にし，河川計画の実務では，年最大值分布で考える ことが基本となっていることを配慮したためであると 考える. しかし, 総合確率法の本質が降雨の各イベン 卜にあるゆえ，仮定 4) に記される通り，洪水を生じさ せるピーク流量に閾值が必要であるとともに，特定の 降雨量を超える降雨パターンを抽出するためには，降 雨量に閾值を設けるのが不可避である。それ故に，実 績降雨の抽出に用いられる間值をあえて表示していな いことを認識しておく必要がある。また, 計画降雨の 超過確率を扱う際には，計画降雨そのものが閾值とな ることから，両者の閾值の扱い方を統一するのがよい.

外力の規模 $y$ （本論では，総降雨量 $R$ ）を越える外力 が 1 年間に来襲する割合を示す生起率関数 $\lambda\left(y, \boldsymbol{\theta}_{1}\right)$ を 次式に示すように導入し, 総合確率法の解釈を再構築 することを討議者は提案する.

$$
\lambda\left(y, \boldsymbol{\theta}_{1}\right)=\exp \left\{-\frac{1}{\xi} \log \left(1+\xi \frac{y-\mu_{1}}{\sigma_{1}}\right)\right\}
$$

ここで, $\mu_{1}, \sigma_{1}, \xi$ のパラメータを 1 組にして $\boldsymbol{\theta}_{1}$ と表 示している。年間来襲数の確率分布を，平均来襲数を $\lambda\left(y, \boldsymbol{\theta}_{1}\right)$ とするポアソン分布で与えれば，規模 $y$ を越え る外力が来襲しない確率は,

$$
F_{1}(y)=\left.\frac{\lambda^{k}\left(y, \boldsymbol{\theta}_{1}\right)}{k !} e^{-\lambda\left(y, \boldsymbol{\theta}_{1}\right)}\right|_{k=0}=e^{-\lambda\left(y, \boldsymbol{\theta}_{1}\right)}
$$

となる（式 (2)の導出と同じ)。これは，年最大值 $y$ の 累積確率分布関数を表し, 式 (15) の生起率関数 $\lambda\left(y, \boldsymbol{\theta}_{1}\right)$ を代入すれば，一般化極值分布となる ${ }^{8)}$. その結果， $\mu_{1}, \sigma_{1}, \xi$ は, 年最大值分布の位置, 尺度および形状母数 に相当することがわかる。

仮定 4) で定義され，式 (4)，(6) および (8) で用いられ る降雨量 $R$ の極大值分布 $G_{\boldsymbol{R}}$ は, 式 (15) の生起率関数 $\lambda\left(y, \boldsymbol{\theta}_{1}\right)$ を用いれば，次式で与えられる。

$$
1-G_{\boldsymbol{R}}(R)=\left.\frac{\lambda\left(y, \boldsymbol{\theta}_{1}\right)}{\lambda\left(u, \boldsymbol{\theta}_{1}\right)}\right|_{y=R}=\left.\left(1+\xi \frac{y-u}{\sigma_{u}}\right)^{-1 / \xi}\right|_{y=R}
$$

ここで， $\lambda\left(u, \boldsymbol{\theta}_{1}\right)$ は，閾值 $u$ を越える降雨量の年間生起 数の期待值であり，椎葉・立川における $\mu T_{y}$ に相当す る (式 (4) を参照)。すなわち，実績降雨の抽出に用い る閾值 $u$ に対しても，式 (15) の生起率が適用できるた
め, 別の記号 $\mu T_{y}$ を使わずに，その扱い方が統一でき たことになる。なお，式(17)にて，

$$
\sigma_{u}=\sigma_{1}+\xi\left(u-\mu_{1}\right)
$$

であり，極大值分布 $G_{R}$ は，一般化パレート分布に相当 する。したがって, 分布関数 $G_{R}$ には間值 $u$ が陽に現 れているが，生起率関数 $\lambda\left(y, \boldsymbol{\theta}_{1}\right)$ には，閾值 $u$ が陽に含 まれていない。これは，式(16)に示すとおり，年最大 值分布に閾値が含まれないことと同じ理由による。た だし，確率は 1 より大きな值をとることができないの に対し，生起率は 1 以上の值をとることができる。す なわち，年間の複数回のイベントの生起を認めている 点が異なる。したがって, 個々の極大降雨を扱うこと を本質とする総合確率法を構築する上では，式 (15)の 生起率関数 $\lambda\left(y, \boldsymbol{\theta}_{1}\right)$ を用いることが望ましいと考える.

\section{(3) 近似の必要のない解釈可能な関係式}

累積確率と生起率の関係が式 (16) となることから, $Q_{p}$ を超えるピーク流量の年間生起率 $\tilde{\lambda}_{1}\left(Q_{p}\right)$ は,

$$
\tilde{\lambda}_{1}\left(Q_{p}\right)=\left.\sum_{i=1}^{N} p_{i} \lambda\left(y, \boldsymbol{\theta}_{1}\right)\right|_{y=R_{i}\left(Q_{p}\right)}
$$

と求めることができる。これは，式 (5) および (6) の両 辺に $\mu T_{y}$ を掛けたものに相当する．また，重み $p_{i}$ が重 要な役割を果たすことは3.で論じる.

椎葉・立川が示した式 (11) および (12)の欠点に，近 似式ゆえのもどかしさがあるのに対し，式(19)には一 切の近似が無く,「結果の生起率は, 原因の生起率の重 み付き算術平均で得られる」と解釈できる。これに加 えて, 前節で述べた通り, 最大值分布による式 (11)お よび (12) と同様，閾值が陽に含まれない簡潔な表現と なる利点がある，なぜなら，極大值の確率分布 $G_{R}$ は， 式 (17) を見るとおり, 閾値を陽に含むため, 数学的な 取扱いが煩雑になる点で，応用上の不利があるからだ.

生起率関数 $\lambda\left(y, \boldsymbol{\theta}_{1}\right)$ を用いる利点は, 年最大值分布お よび極大值分布のいずれを用いても生じる欠点を取り 除くことにある．総合確率法について，端的に言えば, 椎葉・立川による数学的解釈は, 図-2 から図-3 に変換 することを説明していると言える，今日の河川整備計 画が年最大值に対する確率分布を基礎とするゆえ，そ れは当然のことである。しかしながら, 確率分布では なくて，生起率を基礎とすれば，図-4に示すように，極 大值をとる降雨イベント毎に, 降雨量の生起率とピー ク流量の生起率の関係を検討できるということが，討 議者の提案である（図-2の縦軸および横軸に付与され ている確率密度関数の代わりに, 図-4では, 両軸に生起 率を付している点で異なる。降雨パターンのの印が実 績降雨を表し, 線の細太や線種については後述する).

以上から, ピーク流量 $Q_{p}$ の平均生起率は, 式 (19) を用いて算出することを討議者らは奨める。もし，そ 


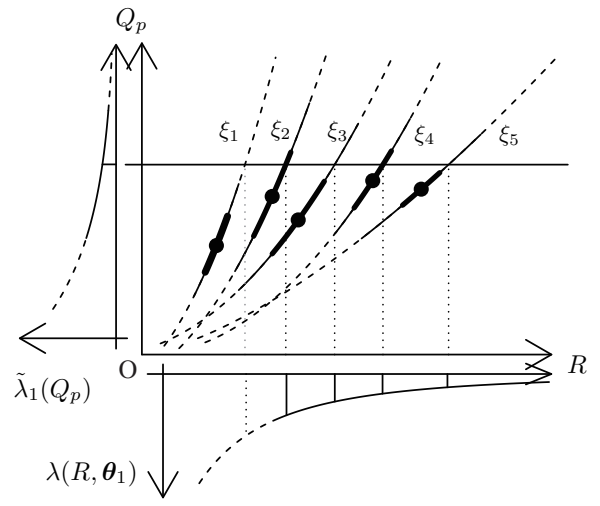

図-4 総降雨が $R$ を超える生起率 $\lambda\left(R, \theta_{1}\right)$ と洪水ピー ク流量が $Q_{p}$ を超える生起率 $\tilde{\lambda}_{1}\left(Q_{p}\right)$ の関係

の年最大值分布 $F_{\boldsymbol{Q}_{p} \max }\left(Q_{p}\right)$ が必要ならば, 次式に代入 することにより，直ちに得られる。

$$
F_{\boldsymbol{Q}_{p} \max }\left(Q_{p}\right)=\exp \left\{-\tilde{\lambda}_{1}\left(Q_{p}\right)\right\}
$$

\section{3. 引き伸ばし率とカバー率の問題}

\section{(1) 短期集中型降雨の外挿による影響}

洪水のピーク流量に対する外捜の限界を，2 種類で 取扱つていると考える。1つめの限界を, 実績降雨が 計画降雨になるように引き伸ばす倍率 (引き伸ばし率) に与える。一般に，降雨継続時間を固定して，時間雨量 を引延ばす。それゆえに，引き伸ばされた時間雨量の ピークが非現実的な值をとるならば，目安の倍率未満 で打ち切る必要はある. 2 つめの限界を, 基本高水とし て定めるピーク流量 $Q$ が, 全ての降雨パターン $\xi_{i=1 \sim N}$ から得られるピーク流量 $Q_{i}\left(R_{\max T}\right)$ （椎葉・立川の図-3 の $\square$ 印を参照）の幾つを上回るものであるかを示す割 合 (カバー率) に用いる。 なお，カバー率における分母 の数の取り方が噯昧に扱われているようにも思う。す なわち，引き伸ばし率で限界を超えたものを除外した 降雨パターンに対する割合として，カバー率を求めて いる場合もあると考える（カバー率 100\% となる場合 の多くは，このような扱いになっているのではなかろ うか?）。教科書 ${ }^{9}$ の説明文には，分母の $n$ には，引き 伸ばし率 2 以上の豪雨も含まれていることは明記され ているが，フローチャートの流れを見ると，「引き伸ば し率 2 倍程度以下」の後に「カバー率 $50 \%$ 程度以上」が ある。そ机ゆえに，分母の数の数え方に誤解が生じる ように思う（ただし，平成 17 年の河川砂防技術基準 10) では，カバー率の用語は消えていることを注意する）。

カバー率は充足率ともよばれ，計画規模の安全度を 高めるために用いるとされている。また，降雨量の割 にピーク流量が大きくなる短期集中型降雨（たとえば, 図-4における $\xi_{1}$ のことである) が引き伸ばされるため に生じる不自然さを取り除くための割合とも言える。 しかしながら，その限界となる数值の選び方が染意的
であると指摘される仕組みになっていることが, カバー 率を用いる方法の問題である.

総合確率法も，短期集中型降雨パターンの影響から 免れないであろう. 式(12)の確率の算術平均において, 椎葉・立川では, 各々の降雨パターンが等しく生起す ると仮定し， $p_{i}=1 / N$ と与えている。短期集中型降雨 パターンに引つ張られ，ピーク流量の超過確率が過大 評価される傾向を否定できない。

総数 $N$ 個の降雨パターンではあるが，実績降雨から 求められる流出流量はそれぞれ異なる。したがって, ある 1 つの流量に限定した時に，各々の降雨パターン が等しい割合で，降雨パターンが割り付けられるのは 不合理と考える。 そこで, 流量 $Q_{p}$ と降雨パターン $\xi_{i}$ に応じて変化するように，式(19) に含まれる重み $p_{i}$ を 与えることを提案する. 図-4 は，実績降雨(○印)の周 辺で重みが大きく，それから離れるにつれて低下し，降 雨パターン $\xi_{i}$ の線種が太-細-破線の順で, 重み $p_{i}$ が低 下するイメージを表している。 しかし，そう考えると， 各々の降雨パターン $\xi_{i}$ における降雨量 $R_{i}$ に応じた重み をどのように与えるか？という問題が新たに生じる.

実績降雨から離孔る（近づく）につれ，その降雨パ ターンの重要度が低く（高く）なるという性質は，交 通計画で用いられる重力モデル ${ }^{11)}$ のようなものと考元 る人もいるかもしれない。ゾーン $i$ で発生する交通量 $G_{i}$ とゾーン $j$ に集中する交通量 $A_{j}$ に対し, ゾーン間 の距離 $d_{i j}$ に応じて分布交通量 $T_{i j}$ を次式のように定め るというものである。

$$
T_{i j}=k \frac{G_{i}^{\alpha} A_{j}^{\beta}}{d_{i j}^{\gamma}}
$$

ここで， $\alpha, \beta, \gamma$ および $k$ はパラメータである. 分母は ゾーン間の距離抵抗を表し, ベキ乗型だけでなく, 指数 関数型やガンマ関数型が提案されている. 例えば, $d_{i j}$ に実績降雨の生起率と計画降雨の生起率の比の対数を, $G_{i}$ および $A_{j}$ に実績降雨と計画降雨の重要度を, それ ぞれ与えて得られる $T_{i j}$ を重み $p_{i}$ と考えることも可能 かもしれない. しかし， $G_{i}$ および $A_{j}$ に代入する重要 度をどう決めるか？ パラメー夕 $\alpha, \beta, \gamma$ および $k$ をどう 決めるか？決めるべきものの数が多すぎる，このよう な扱い方は染意的かつ便宜的にならざるを得ず，大き な問題を残す。

\section{(2) 経験度の利用}

極值統計解析による外挿の限界を検討するため, 経験 度という概念が導入され ${ }^{12)}$ ，水工学分野でも応用され つつある例えば 8)，外挿によって推定される值に対し， その推定に用いた実質的なデー夕数を示すものとして, 経験度の值が算出される。経験度の最大值は，実績降 雨のデー夕数そのものであり, 実績降雨から引き伸ば 
して, 外挿された降雨量の対しては, 生起率の低下と ともに，経験度も低下する。

式 (19) を用いて得られる確率流量 $Q_{p}$ の推定誤差も 検討すべきと考えるなら，式 (19) に現れる重み $p_{i}$ は デー夕数に相当する量で与えられるべきと考える。 な ぜなら，数理統計学は，次式で表されるように，標本 平均の分散がデー夕数 $n$ に逆比例することを基礎に構 築されているからである $\left(X_{i=1 \sim n}\right.$ を独立な確率変数, $V$ は分散を表し，例えば，大数の弱法則は，次式より導 かれるのが一般的である).

$$
V\left(\sum_{i=1}^{n} \frac{X_{i}}{n}\right)=\frac{V\left(X_{1}\right)}{n}
$$

したがって，推定に用いた実質的なデー夕数を示す経 験度を使って, 重み $p_{i}$ を与えれるならば, 確率流量 $Q_{p}$ の推定誤差を検討するには都合がよいと考える。重み $p_{i}$ の具体的な与え方や確率流量 $Q_{p}$ の推定誤差（ある いは信頼区間）の求め方については，討議の紙面に制 約があるため，別の機会に論じたい.

\section{(3) 残された問題の解消と新たに生じる問題}

仮定 1)に述べられている, 総雨量の生起分布と降雨 パターンの選択の独立性が成り立たなければ，総合確 率法の根拠を失う重大な問題点と考える。当時の淀川 の治水計画に，総合確率法そのものが適用されなかっ た主原因はここにあると考える。その代わりに，淀川 の治水計画で実際に導入され，現在，多くの河川で慣 用的に用いられる方法は，原因を 1 つに限定し，原因 の確率を「平均」しない。これは，独立性の仮定を避 けたためと考える。

雨量と降雨パターンの組合せにおける独立性の問題 は，流量を条件として選択される降雨パターンの機会 の均一性にあると言える。それゆえに，前節で提案す るとおり，各々の降雨パターンに，実績に応じた重み を付けて平均すれば，この問題点は回避できたことに なる，重みを与えることにより，総雨量と降雨パ夕ー ンを独立に組合わせることなく，対象とする計画降雨 に対して，実績の関係を援用する方法で，降雨パター ンを関連づけたと解釈できるからである．仮定 3) で述 べられている，降雨パターン $\xi_{i}$ が生起する確率 $p_{i}$ は実 績降雨に対するものであり, 式 (19) で用いる重み $p_{i}$ は 計画降雨に対するものである点が，全く異なる．流出 流量 $Q_{p}$ に対する計画降雨量 $R_{i}$ に重み $p_{i}$ は依存してい るのである。

単純な平均ではなく, 重み付き平均である点で, さ らに概念的という批判もあるかもしれない. 結果の確 率を求めるために，複数の原因の確率に遡ることを本 質とする総合確率法には，「平均」の概念は避けられな い.そもそも外挿により計画外力を検討するためには, 概念的にならざるをえない，既往最大の 1.1 倍で計画
外力を考えることが単純明解であるという意見 ${ }^{13)} も あ ~$ るが，これも実績を引き伸ばす手法の1つである限り， なんらかの概念を用いた根拠の提示から免れてもよい はずは無い。

仮定 2) で約束されるピーク流量に対する総降雨量の 単調増加性は, 確率分布の定義として, 流量 $Q_{p}$ の累積 確率が単調に増加する条件を満足させるために設けて いると討議者は考えている，ただし，その保証は，流量 $Q_{p}$ が変化しても重み $p_{i}$ が一定となる場合に限る。式 (19) において, 確率流量 $Q_{p}$ とともに重み $p_{i}$ が変化す ると, 生起率 $\tilde{\lambda}_{1}\left(Q_{p}\right)$ が単調減少 (累積確率 $F_{\boldsymbol{Q}_{p} \text { max }}\left(Q_{p}\right)$ が単調増加）しない可能性がある。具体的に計算すれ ば，ある流量以上の生起率で，その新たな問題が生じ るかもしれない.

計画規模の洪水ピーク流量を, 原因となる降雨に遡つ て, 水理学的な流出計算と生起確率を融合させて求め ること自体が工学的な都合であり，その論理のどこか で破綻を招いても不思議はないと考える。むしろ，そ のようなことを明示的に示せることも，それがどこま で適用できる論理であるかを第三者に公平に示す根拠 になるのではないだろうか？討議の紙面の制約ゆえ， その詳細は別の機会に譲る。

討議の結論として, 総合確率法による確率流量 $Q_{p}$ の 算定には，利根川の治水計画で用いられている式 (12) を発展させ，生起率の重み平均で表される式(19) を用 いるのが良いと考える．また，その際に必ずしも等重 みを前提としないことに重要な意味がある。これらの 点について，著者の意見を求めたい.

\section{参考文献}

5) 大町利勝: 計画洪水流量決定手法に関する一考察, 水文 水資源学会誌，Vol. 17, No. 2, pp. 170-179, 2004.

6) 大熊 孝: ダム論争の焦点脱ダムに阻む「基本高水」一さ まよい続ける日本の治水計画，世界，岩波書店，No. 731， pp. 123-131, 2004.

7) 椎葉充晴, 立川康人 : 総合確率法の数学的解釈, 土木学 会論文集 B1（水工学), Vol. 69, No. 2, pp. 101-104, 2013.

8）北野利一, 高橋倫也, 田中茂信: 降水量の極值の予測区間 〜確率降水量の信頼区間を誤解していませんか?, 土木 学会論文集 B1（水工学), Vol. 69, No. 4, pp.I_271-I_276, 2013.

9) 高橋 裕: 新版 河川工学, 東京大学出版会, 318p., 2008.

10）国土交通省河川局監修：国土交通省河川砂防技術基準 同 解説・計画編，技報堂出版，230p., 2005.

11) 森地 茂, 山形耕一編著: 交通計画, 新体系土木工学 60 , 技報堂出版, 296p., 1993 .

12）北野利一, 森瀬喬士, 喜岡 渉, 高橋倫也 : 確率波高に 対する推定の可否を決定づける新たな指標の提案, 海岸 工学論文集, Vol. 55, pp. 141-145, 2008.

13）関 良基: 基本高水はなぜ過大なのか一国交省の作為と 日本学術会議の「検証」を問う，世界，岩波書店，No. 822， pp. 296-306, 2011.

(2013. 9. 19 受付) 
著者らの研究に対して貴重な意見を頂くとともに， 回答する場を与えられたことに対し，討議者に感謝申 し上げる、以下，式番号は筆者らの論文 ${ }^{14)}$ および北野 らの討議で付された式番号を用いる。

総合確率法は，降雨の時空間分布パターンを考慮し た上で，任意の再現期間に対応する年最大洪水ピーク 流量を求める手法であり，いくつかの河川流域に適用 されている，総合確率法の解説には手順は示されてい るが，その基本的な考え方を示した原著論文が見当た らず，その背景にある仮定やそれから導かれる理論が 明らかではない.これらを明らかにすることによって, 妥当性や限界を理論的に議論することが可能となり, 今後の展開を期することができると考えた。

総合確率法の考え方を理論的に導く上で，筆者らが 設定した仮定 ${ }^{14)}$ を再掲すると以下のようである。これ らの仮定は, 総合確率法を理論的に導くために必要と 考えられる事項を明らかにしたものである。

仮定 1) ある降雨期間内の総降雨量と降雨の時空間的 分布パターンは独立である。

仮定 2)いずれの降雨においても, 降雨パターンを固 定し総降雨量だけを変化させた場合, 総降雨量と ともに洪水ピーク流量は単調に増加する.

仮定 3) 降雨の時空間的分布パターンは, 有限個のパ ターンだけをとるとして，ある降雨パターンが生 起する確率は与えられているとする。 また, 降雨 期間は固定する.

仮定 4) 洪水（たとえばある地点の洪水ピーク流量 が，事前に定められたある特定の洪水ピーク流量 を超える事象）を生じさせるような降雨の発生は ポアッソン過程に従うとし，そうした降雨事象が 発生したときの総降雨量の確率分布は, 発生時点 とは独立に，同一の分布関数に従うとする.

北野らは，これらの仮定のもとで，ある值を超える降 水量が年間に生起する回数を示す生起率関数 (式 (15)) を用いた総合確率法の新しい見方を示している．筆者 らが示した年最大総降雨量の分布関数と年最大ピーク 流量の分布関数との関係式 (9) やその近似式 (11), 総 合確率法で用いられる式 (12) は，ある降雨期間内の総
降雨量の年最大值の確率分布を用いて年最大ピーク流 量の確率分布を導出する式である. 仮定 4) に現れる総 降雨量の確率分布（極大值分布）は，これらの式を誘 導するために必要となるが, その具体的な関数形は必 要としない. 必要となるのは，ある降雨期間内の総降 雨量の年最大值の確率分布関数である。一方で, 北野 らは, 極大值分布や年最大值分布のもととなる降雨事 象の生起率関数を設定して，ある值を超えるピーク流 量の年間生起率や年最大值分布を導出した。両者の考 え方に本質的な違いがあるわけではないが，北野らの 生起率関数を用いれば, 年最大值とは限らない個々の 降雨発生からピーク流量の年最大值分布までを見通し よく説明することができる。

もう一つの改良点として, 北野らは, 仮定 1), 3) に 関連して, 降雨パターンおよび降雨量に応じて降雨の 生起確率を変化させることを提案しており, その具体 的な成果が期待される。筆者らは降雨の時空間パター ンについて, 降雨パターン $i$ が生起する確率を $p_{i}$ とし て一般的に議論を進め, この值を等しいとする場合に 総合確率法で用いられる式 (12) が導かれることを示し た. 大町 ${ }^{15)}$ は, 淀川流域の工事実施基本計画が策定さ れた当時の総合確率法による検討過程を述べ, 降雨パ ターンや雨量によらずその生起確率を等しく設定する ことから生じる困難とそれを回避するための補正法が 検討されたことを紹介している。

総合確率法は, その理論的な枠組みの中で総降雨量 の確率分布と降雨の時空間分布パターンを取り込み, 年 最大ピーク流量の確率分布を求めようとするところに 特徵がある。その導出の背景にある仮定の妥当性を検 証し, 総降雨量と降雨分布パターンに応じて合理的な 生起確率を設定することができれば，新たな洪水ピー ク流量の設定手法に発展する可能性がある.

\section{参考文献}

14) 椎葉充晴, 立川康人 : 総合確率法の数学的解釈, 土木学 会論文集 B1 (水工学), Vol. 69, No. 2, pp. 101-104, 2013.

15) 大町利勝: 計画洪水流量決定手法に関する一考察, 水文・ 水資源学会誌，Vol. 17, No. 2, pp. 170-179, 2004.

(2014. 2. 25 受付) 